\title{
Challenges in Meeting Surgical Needs in the Developing World: Reply
}

\author{
Richard Gosselin • Yaw Adu-Gyamfi • \\ Sandro Contini
}

Published online: 9 April 2011

(c) Société Internationale de Chirurgie 2011

We are grateful to Dr. Senanayake for his pertinent comments. We cannot agree more with him that socioeconomic determinants play a fundamental role in the health sector. Sri Lanka appears to be ahead of similar resource-constrained countries in terms of its health care system. In countries where fewer resources are allocated to the health sector, we have unfortunately too often seen surgeons returning from training abroad with knowledge requiring unavailable, inappropriate, or unsustainable technology.
Training abroad is beneficial when it "opens the mind," but less so if it implies re-allocation of already scarce resources at home. The negative effects of the brain drain might offset the benefits of training abroad. To our knowledge, this has not been studied. We agree that a broader scope of research, including studies on traditional remedies, is needed, and should figure higher in the prioritization process. 